\title{
The Effects of Different Approaches to Salary Survey Data Analysis on Pay Curve Midpoint Values
}

\section{R J Snelgar}

Department of Industrial and Organisational Psychology, University of Port Elizabeth

\begin{abstract}
Despite the acceptance of salary survey market data as justification for salary differentials, the whole area of collection, analysis, and interpretation has not been subject to the same scrutiny as hiring practices and testing. Many aspects of surveys have been ignored by researchers. Little can be said about the effects of different formats in the accuracy of data obtained, about ensuring comparability of job matches, about how representative relevant markets surveys are, or about reliability of analysis of survey results. This study has revealed the extent to which individual survey position averages have been obscured by the inclusion of data from different position grades. As a result, different approaches to the analysis of data from the same salary survey have resulted in different pay lines/curves.
\end{abstract}

JEL I12, I30

\section{INTRODUCTION}

A market/salary survey is the systematic process of collecting and making judgments about the compensation paid by other employers (Milkovich \& Newman, 2002: 231). Such surveys provide the data for setting pay policy relative to competition, and translating that policy into pay levels and structures. A salary survey provides a snapshot of the market situation at a set time, allowing the user a base from which to work. Salaries move at varying rates throughout the year due to staff turnover, supply of and demand for skilled and unskilled workers, social pressures, and inflation. In order to keep abreast of salary movements it is necessary to measure the market from one fixed date to another, over a period of time.

Most companies participate in several different salary surveys, while some writers claim that large employers participate in up to 100 surveys in a single year, although the data from only a few of these surveys are used to make 
compensation decisions (Gerhardt \& Milkovich, 1992). Most organizations make adjustments to employees' pay on a regular basis, and salary surveys provide information on pay rates among other employers. Periodic changes must be known to adjust or maintain a company's pay level in relation to its competitors, and since salary surveys are the only means whereby this may be done, pay structures can depend heavily on the data obtained from these surveys. Many employers also use salary surveys to validate their own job evaluation results (Rynes \& Milkovich, 1986: 71-90). The job structure that results from job evaluation may not match the pay structure found in the market, and reconciling these two pay structures is a major issue.

These are some of the factors that illustrate that the survey is one of the most helpful tools available to the compensation manager, emphasizing the importance of surveys in the overall compensation decisions of companies.

\section{SURVEY DATA RELIABILITY}

However, the reliability of the data, and comparability of the positions that are used as a basis for calculating position averages in salary surveying, should be a matter of serious debate and research. The driving force behind this assertion is the fact that these surveys are used by most companies to adjust their own rates of pay, and nationally, this could be highly inflationary (Viswesvaran \& Barrick, 1992).

Some of the major problems that restrict the gathering and analysis of data for making pay decisions that relate to competitive market conditions are identified as obtaining the proper job match, collecting comparable pay data, integrating market pay data with internally generated job-worth data and pay structure design, and analyzing and making inferences from collected pay data (Milkovich \& Newman, 2002: 229-262). Survey results may vary because of differences in sampling procedures, statistical methods used, and how jobs are defined (Werner, Konopaske \& Touchey, 1999). Wage and salary data obtained from market surveys are not definitive. After adjusting for job content, company size, company performance, and geographic location, differences ranging from 35 per cent to 300 per cent in the pay of identical jobs within the same industry are not uncommon (Gerhardt \& Milkovich, 1993). Also, pay practices of companies are often widely divergent, and this is frequently ignored when competitive pay is analyzed and discussed (Foster, 1985; Werner et al., 1999, Lichty, 2000).

According to one researcher, the quality of many surveys is low because companies fill out surveys carelessly, and instead of using their more 
experienced compensation staff to complete surveys, they often assign the task to entry-level employees, or even clerical personnel. As a result, the responses provided may not be as thorough or complete as when the surveys are completed by more experienced professional staff (Werner \& Gemeinhardt, 1993).

Despite the acceptance of United States courts of market data as legal justification for salary differentials, the whole area of collection, analysis, and interpretation has not been subject to the same scrutiny as hiring practices and testing. The same ruling has not been made in South African courts, but the latter statement definitely holds true. Certainly, a sound, business related rationale for every step in the process is important. Some survey data profile a general guide to assess the adequacy of the whole pay structure, but not necessarily pay of specific jobs. Other surveys are designed to price specific jobs, and still others to assess only the rate of change in the rates paid. Thus, even the purpose of the survey needs to be kept in mind when judging the accuracy of data.

Many aspects of salary surveys have been ignored by researchers. Little can be said about the effects of different formats in the accuracy of the data obtained. Little is known about ensuring comparability of job matches or benefit packages. Little is known about how representative surveys are of some markets. The same lack of research plagues the analysis of survey results. However, some research has been done in the area of different survey techniques/methods, and approaches to survey results analysis, and this research has revealed the extent to which these differing approaches affected a single pay structure over a seven-year period (Snelgar, 1984; Snelgar, 1986).

Belcher, Ferris and O’Neill (1985) interviewed 34 compensation professionals and questioned them as to how survey data was actually analyzed. They discovered that every organization uses its own methods of distilling information from surveys, uses different surveys for different purposes, and uses different methods of analysis by industry, by firm size, or by union presence. It would seem that diversity rules in analyzing survey data. However, while it may be that diversity reflects the flexibility of managers to adjust their analysis to deal with a variety of circumstances, the concern is that diversity reflects the lack of business and work related logic, and such approaches will not be able to withstand close critical scrutiny.

Opinions about the value of consultant surveys are rampant, but research is not. Many companies select one survey as their primary source and use others to cross-check or "validate" results. As far as staffing decisions are concerned, employment test designers report the test's performance against a set of standards (reliability, validity, etc.). It is accepted that there are generally 
accepted standards of practice in most professions such as Accountancy, Law, the Buildings disciplines, etc., but for pay decisions professional standards do not exist. Issues of sample design and statistical inference are seldom considered. It has been found that some employers combine the results of several surveys and weight each survey in this composite according to some person's judgment of the quality of the data reported (Hartenian \& Johnson, 1991: 367). No systematic study of differences in market definition, participating firms, types of data collected, quality of data, analysis performed, and/or results is available.

\section{DATA COLLECTION}

All basic forms of pay need to be covered in a survey to assess the similarities and differences in the entire pay packages and to accurately assess competitor's practices (Rich \& Phalen, 1992). However, the most important data in the survey are the actual rates paid to each incumbent. Total earnings, hours worked, date and amount of last increase, and bonus and incentive payment are included. Enough data must be available to appraise the match between the benchmark jobs in the survey and the jobs within each company. The degree of match between the survey's benchmark jobs and each company's jobs is assessed by various means, but there is no standard means of doing this. Suggestions are available as to how to assess the quality and accuracy of the data for each company (Werner et al., 1999). Nevertheless, possibly the most critical deficiency or opportunity for error in a survey is in matching the pay of different jobs, and thus, job matching is a critical problem in conducting a useful and valid salary survey. It is this matching of pay that will ultimately determine the market rates, or "going rates" for the jobs in the survey.

\section{$4 \quad$ THIS STUDY}

\subsection{Position comparability}

It is precisely in this area of job matching that comparability of salary survey data defines the problem to be investigated by this study. For each position to be surveyed the surveying company makes comparisons by job title and capsule job description, and uses these comparisons to collect and collate data. Based on this data collected, averages are calculated for each position, which will provide the basis for each individual company to adjust their own data. The fact that comparisons are made by position title and capsule job description does not mean that the positions are in fact comparable. It is quite likely that the positions that are compared on this basis differ in job content, and this is 
revealed by the job evaluation grading of each position. Should the job evaluation grading of these positions differ, then this indicates that the job content is different, and in fact they are not comparable. Averages of such positions are then not reliable or valid, and calculations and adjustments that are made according to such averages are in turn not reliable or valid.

It becomes clear that the data provided for each position may well differ should calculations be made by position grade rather than position title and description. Thus, should a company adjust its pay structure data based on the survey averages calculated for each position title and description, this adjustment is likely to differ considerably compared to adjustments made according to the actual salary averages or grade midpoint averages calculated for positions that are in the same grade. This reflects the problem that different companies use different data from surveys to adjust both individual position data, as well as overall pay structure data, and this in turn reflects inconsistencies in salary survey data interpretation.

The intention of this study is thus to test the above contention, and to determine the degree to which data can vary, depending on data interpretation and usage.

\subsection{Method}

The intention of this study is to duplicate the method of data collection used by most salary survey approaches, and in this way duplicate the range of data and information presented to participating organizations. Thus, a survey method was used to collect basic salary data from 13 organizations for 8225 staff members. This sample was defined by the labour market relevant to a particular industry. A survey of a labour market differs from the usual notion of a statistically accurate sample of a population. Salary surveys in general focus on a narrower population, and the relevant population depends on the purpose of the survey. This survey labour market included those organizations that are competitors for employees, with an emphasis on product/service market specific skills. Care was taken to collect basic salary data only (basic rate of salary per month, excluding bonuses, overtime payments, any other allowances, and other benefits), and exclude any other form of compensation that might have been relevant to each position. This was achieved by sending out capsule job descriptions for each position surveyed whereby organizations could establish job matches and supply basic salary data for each position incumbent. Organizations were required to supply job evaluation grades for each position. Each organization uses the same job evaluation method to evaluate its jobs. 


\subsection{Data analysis}

For each position individually weighted averages (average per company), organization weighted averages (average per sample), inidividual position grades, and modal grades were tabulated. Care was taken to calculate organization weighted averages per job evaluation grade, as well as overall organization weighted averages, for each position. It must be emphasized that each position summary included data that was drawn from a range of different grades, depending on each organization's evaluation of that position.

From this data an overall market pay line was calculated by graphically plotting organization weighted averages for all the surveyed positions, and using a regression analysis to generate the line that best fits the data by minimizing the variance around the line. This provides a statistical summary of the distribution of the going rates paid by the participants in this survey, or the market pay line/curve for this set of survey participants. This market pay line provided the midpoint values for each grade.

Averages for each position were then calculated for one particular participating organization, but strictly according to the matching job evaluation grade for each position. In other words, the general organization weighted averages were not used for each position (as these included position averages from a range of different grades), but rather only those individually weighted averages applicable for those positions that were in the same grade as those of this particular organization. In this manner job evaluation grade-based organization weighted averages were calculated for each position. A regression analysis was once again used to calculate the midpoint values for each grade.

A further pay line was calculated by using the modal grades calculated for each position. Modal grade averages were then calculated for each position and once again a regression analysis used to calculate pay line midpoint values.

\subsection{Results}

Tables 1, 2 and 3 reflect the position data collected from each organization, and reflect not only overall organization weighted base salary averages ("position average" column), but also organization weighted base salary averages by grade ("grade average" column), for each position. The relevant grades are reflected in brackets behind each separate average for each position. This analysis has been done to reflect the fact that the overall average is obscured by the inclusion of a range of different grade averages for each position. Thus, separate averages have been calculated and reflected for each grade that has been included in the sample for each position. Each table reflects a sample of different categories of staff. 
Table 1 Organization weighted averages per position: Professional staff

\begin{tabular}{|l|c|c|c|c|c|}
\hline Position & $\begin{array}{c}\text { Position } \\
\text { average }\end{array}$ & $\begin{array}{c}\text { Grade } \\
\text { average }\end{array}$ & $\begin{array}{c}\text { Grade } \\
\text { average }\end{array}$ & $\begin{array}{c}\text { Grade } \\
\text { average }\end{array}$ & $\begin{array}{c}\text { Grade } \\
\text { average }\end{array}$ \\
\hline A & 50489 & & & & \\
\hline B & 38716 & $57900(1)$ & $39261(2)$ & $26770(3)$ & \\
\hline C & 32778 & $46536(1)$ & $41382(2)$ & $33352(3)$ & $24246(4)$ \\
\hline D & 25515 & $26739(4)$ & $23982(5)$ & & \\
\hline E & 28182 & $36662(3)$ & $21121(4)$ & $17928(5)$ & \\
\hline F & 20547 & $26637(4)$ & $16968(5)$ & $16022(6)$ & $11943(7)$ \\
\hline G & 23046 & $21548(4)$ & $22287(5)$ & & \\
\hline H & 18437 & $17254(5)$ & $18033(6)$ & & \\
\hline I & 15269 & $14501(6)$ & $15346(7)$ & & \\
\hline J & 12043 & $10306(8)$ & $12740(7)$ & & \\
\hline K & 8555 & $8513(9)$ & $8693(10)$ & & \\
\hline M & 14944 & $15081(7)$ & $16096(6)$ & & \\
\hline N & 11796 & $12137(8)$ & & & \\
\hline \hline
\end{tabular}

Table 2 Organization weighted averages per position: Administrative staff

\begin{tabular}{|l|c|c|c|c|c|}
\hline Position & $\begin{array}{c}\text { Position } \\
\text { average }\end{array}$ & $\begin{array}{c}\text { Grade } \\
\text { average }\end{array}$ & $\begin{array}{c}\text { Grade } \\
\text { average }\end{array}$ & $\begin{array}{c}\text { Grade } \\
\text { average }\end{array}$ & $\begin{array}{c}\text { Grade } \\
\text { average }\end{array}$ \\
\hline A & 22352 & $24922(5)$ & $20323(4)$ & & \\
\hline B & 20636 & $16418(6)$ & $30021(4)$ & $13649(7)$ & \\
\hline C & 15945 & $17160(5)$ & $15828(6)$ & $13863(7)$ & \\
\hline D & 24184 & $48528(3)$ & $19263(4)$ & $19033(5)$ & $16150(6)$ \\
\hline E & 18281 & $33063(4)$ & $18115(5)$ & $15500(7)$ & \\
\hline F & 16177 & $33452(4)$ & $16441(5)$ & $16911(6)$ & $14559(7)$ \\
\hline G & 23071 & $31350(3)$ & $24784(4)$ & $19833(5)$ & \\
\hline H & 8452 & $10192(7)$ & $11394(8)$ & $7697(11)$ & \\
\hline I & 8386 & $8652(9)$ & $8764(10)$ & $9161(11)$ & $5850(12)$ \\
\hline J & 15340 & $16327(6)$ & $12378(8)$ & & \\
\hline K & 6674 & $11083(8)$ & $10397(9)$ & $7424(10)$ & $6466(11)$ \\
\hline L & 11121 & $11601(7)$ & $12076(8)$ & $9016(9)$ & \\
\hline M & 8260 & $8413(9)$ & $7911(10)$ & & \\
\hline N & 6728 & $5551(8)$ & $7222(10)$ & $5286(11)$ & \\
\hline O & 4896 & $5653(11)$ & $5026(12)$ & & \\
\hline P & 14124 & $15232(6)$ & $13426(7)$ & $11597(7)$ & \\
\hline
\end{tabular}


Table 2 continued

\begin{tabular}{|l|c|c|c|c|c|}
\hline Position & $\begin{array}{c}\text { Position } \\
\text { average }\end{array}$ & $\begin{array}{c}\text { Grade } \\
\text { average }\end{array}$ & $\begin{array}{c}\text { Grade } \\
\text { average }\end{array}$ & $\begin{array}{c}\text { Grade } \\
\text { average }\end{array}$ & $\begin{array}{c}\text { Grade } \\
\text { average }\end{array}$ \\
\hline $\mathrm{Q}$ & 9569 & $10707(8)$ & $8522(9)$ & & \\
\hline $\mathrm{R}$ & 8623 & $11174(8)$ & $9175(9)$ & $7462(10)$ & $7563(11)$ \\
\hline $\mathrm{S}$ & 8898 & $7902(6)$ & $10529(9)$ & $11098(9)$ & $7376(10)$ \\
\hline $\mathrm{T}$ & 6853 & $6604(11)$ & $6852(12)$ & & \\
\hline $\mathrm{U}$ & 26320 & $32989(3)$ & $27014(4)$ & $18592(5)$ & \\
\hline $\mathrm{V}$ & 16617 & $18238(5)$ & $17755(6)$ & $14292(7)$ & \\
\hline $\mathrm{W}$ & 12427 & $15078(7)$ & $10703(8)$ & & \\
\hline $\mathrm{X}$ & 10062 & $10399(8)$ & $8162(9)$ & $9634(10)$ & \\
\hline $\mathrm{Y}$ & 7002 & $8848(9)$ & $7053(10)$ & $5220(11)$ & $8455(12)$ \\
\hline
\end{tabular}

Table 3 Organization weighted averages: General staff

\begin{tabular}{|c|c|c|c|c|c|}
\hline Position & $\begin{array}{c}\text { Position } \\
\text { average }\end{array}$ & $\begin{array}{c}\text { Grade } \\
\text { average }\end{array}$ & $\begin{array}{c}\text { Grade } \\
\text { average }\end{array}$ & $\begin{array}{c}\text { Grade } \\
\text { average }\end{array}$ & $\begin{array}{c}\text { Grade } \\
\text { average }\end{array}$ \\
\hline A & 18589 & $20647(5)$ & $18051(6)$ & & \\
\hline B & 9930 & $11831(8)$ & $7519(10)$ & & \\
\hline C & 14628 & $14861(7)$ & $16172(5)$ & $15821(6)$ & \\
\hline D & 8414 & $11152(8)$ & $8325(9)$ & $8270(10)$ & \\
\hline E & 5874 & $6269(11)$ & $5253(13)$ & & \\
\hline F & 15811 & $15155(5)$ & $15731(6)$ & $15172(7)$ & $12632(8)$ \\
\hline G & 11751 & $14333(7)$ & $11198(8)$ & $10186(9)$ & \\
\hline H & 11169 & $13934(7)$ & $12977(8)$ & & \\
\hline I & 8078 & $11872(9)$ & $7170(10)$ & $6724(11)$ & \\
\hline J & 5159 & $7196(11)$ & $4968(12)$ & $4155(13)$ & \\
\hline K & 5777 & $7267(10)$ & $6029(11)$ & $5498(12)$ & \\
\hline L & 6339 & $6086(10)$ & $6146(11)$ & $6793(12)$ & \\
\hline M & 5261 & $6541(11)$ & $5661(12)$ & $5088(13)$ & \\
\hline N & 13262 & $13835(6)$ & $16331(7)$ & $10293(9)$ & \\
\hline O & 11275 & $15021(7)$ & $11387(8)$ & $9007(9)$ & \\
\hline P & 14463 & $14670(6)$ & $14324(7)$ & & \\
\hline Q & 8856 & $9030(9)$ & $8923(10)$ & & \\
\hline R & 12060 & $15044(6)$ & $13404(7)$ & $11443(8)$ & \\
\hline S & 9522 & $14191(6)$ & $9218(8)$ & $9161(9)$ & $8186(10)$ \\
\hline T & 4861 & $4987(12)$ & $3859(13)$ & $5204(14)$ & \\
\hline U & 18383 & $20568(4)$ & $23399(5)$ & $13867(6)$ & \\
\hline V & 10706 & $13463(7)$ & $9819(8)$ & $11073(9)$ & \\
\hline W & 7743 & $8796(9)$ & $7376(10)$ & & \\
\hline & & & & & \\
\hline
\end{tabular}


Table 3 continued

\begin{tabular}{|c|c|c|c|c|c|}
\hline Position & $\begin{array}{c}\text { Position } \\
\text { average }\end{array}$ & $\begin{array}{c}\text { Grade } \\
\text { average }\end{array}$ & $\begin{array}{c}\text { Grade } \\
\text { average }\end{array}$ & $\begin{array}{c}\text { Grade } \\
\text { average }\end{array}$ & $\begin{array}{c}\text { Grade } \\
\text { average }\end{array}$ \\
\hline X & 13908 & $23934(5)$ & $15044(6)$ & $12186(7)$ & $11298(8)$ \\
\hline Y & 8186 & $10601(8)$ & $8811(9)$ & $6710(10)$ & \\
\hline Z & 4011 & $4442(13)$ & $3972(14)$ & & \\
\hline AA & 3875 & $3511(13)$ & $3485(14)$ & $2753(16)$ & \\
\hline BB & 2985 & $3830(15)$ & $3023(16)$ & & \\
\hline
\end{tabular}

Table 4 illustrates the variance in the midpoint values of the different pay lines, or curves, as calculated subsequent to the regression analyses. These pay lines reflect the different approaches to data analysis outlined in the data analysis section of this study.

Table 4 Pay line midpoint values

\begin{tabular}{|c|c|c|c|}
\hline $\begin{array}{c}\text { Grade } \\
\text { number }\end{array}$ & $\begin{array}{c}\text { Company grade } \\
\text { av. pay line }\end{array}$ & $\begin{array}{c}\text { Position av. pay } \\
\text { line }\end{array}$ & $\begin{array}{c}\text { Modal grade pay } \\
\text { line }\end{array}$ \\
\hline 17 & 33581 & 29436 & 34808 \\
\hline 16 & 38513 & 35680 & 39098 \\
\hline 15 & 44167 & 43245 & 43930 \\
\hline 14 & 50653 & 52415 & 49355 \\
\hline 13 & 58091 & 63529 & 55427 \\
\hline 12 & 66620 & 77000 & 62278 \\
\hline 11 & 81426 & 93327 & 76586 \\
\hline 10 & 99524 & 113116 & 94182 \\
\hline 9 & 121644 & 137102 & 115830 \\
\hline 8 & 148679 & 166174 & 142441 \\
\hline 7 & 181723 & 201409 & 175164 \\
\hline 6 & 222112 & 244115 & 215411 \\
\hline 5 & 271477 & 295879 & 264911 \\
\hline 4 & 331814 & 358619 & 325776 \\
\hline 3 & 405560 & 434661 & 400620 \\
\hline 2 & 495696 & 526826 & 492677 \\
\hline 1 & 605867 & 638537 & 605867 \\
\hline
\end{tabular}

\section{DISCUSSION}

Tables 1, 2, and 3 reveal that there are a number of different grade averages that are used to calculate the overall average for each position. These individual grade averages have deliberately been separated from the overall average for 
each in order to reveal the wide variances in grade averages that are included in the overall averages of positions. Any one of these averages can be used by a company as a reference point when attempting to establish a reference point for its own comparable position. The important point to make at this stage is that if positions are in fact in different grades, it emphasizes the fact that job content differs, and as such the positions are therefore not comparable, despite the fact that titles may be the same, and despite the fact that capsule job descriptions may reflect a level of comparability. To reflect overall position averages (or weighted company averages) that include data from a range of grades obscures the data. Such data that is used for salary adjustments is therefore not reliable.

Table 4 reflects the differing pay lines, or curves, depending on the approach to data analysis. The pay line has been chosen as that set of data that represents the overall reference point that is generally used by organizations to adjust their own pay line levels, or structures. Although these sets of data have been calculated from the same survey, the fact that there is no set method of data analysis that has been researched and specified, results in vastly differing outcomes, depending on the individual company's interpretation of how data analysis should be conducted. It must be noted that even though individual position averages were calculated according to the relevant grades of one particular company, and a pay line calculated from these (reflected in the company grade averages pay line), these figures are likely to differ for any of the other participating companies using the same approach, but using its own position grades. In effect, differing pay lines will emerge for each company.

These different pay lines reveal clearly that the adjustments that are made to company pay structures may vary considerably, both within a particular organization, as well as between organizations.

\section{CONCLUSION}

As mentioned in the introduction to this study, the problems associated with the various facets of salary survey data compilation, and interpretation may well have an effect on the reliable adjustment of a company's pay structure, and/or individual position salary adjustments. This study has revealed that there is an obscuring of the data that is usually presented by salary surveys, and this is as a result of including data from positions that are not comparable. This affects data reliability. In order to reveal the compounded affect of different approaches to data analysis, regression analyses reveal that different pay lines may be calculated from the same set of data. Thus, different companies may be using the same survey, but the results in their salary adjustments may well be vastly different. This effect is compounded over years, and has an effect on the overall market rates as well. 
Although there are a number of areas to be researched in the sphere of salary surveys, an important approach aimed at reducing the level of anomalies is to survey by job evaluation grade rather than individual position. It is agreed that each grade has a midpoint that is recognized as the going rate for all the positions falling within that grade, and therefore the midpoint is the reference point that can be used for survey purposes. The only data that needs to be gathered in this approach are the grade midpoints of each participating company. These midpoints are comparable across respective markets, and are not obscured by unreliable data. Although the ideal approach is for each company to be using the same job evaluation system, different systems are also comparable, and it is possible to establish comparable grades between systems. In this way the groundwork for comparable data is established, and the possibility of contaminating data is reduced.

\section{REFERENCES}

1 BELCHER, D.W., FERRIS, B. \& O’NEILL (1985) "How wage surveys are being used”, Compensation and Benefits Review, (SeptemberOctober): 34-51.

2 FOSTER, K.E. (1985) “An anatomy of company pay practices” Personnel: 66-72.

3 GERHARDT, B. \& MILKOVICH, G.T. (1992) "Employee compensation”, in M.D. Dunnette \& L.M. Hough (eds.) Handbook of Industrial and Organizational Psychology, 2, Consulting Psychologists Press: Palo Alto, CA.

4 GERHARDT, B. \& MILKOVICH, G.T. (1993) "Employee compensation: research and practice”, in M.D. Dunnette \& L.M. Hough (eds.) Handbook of Industrial and Organizational Psychology, 3, Consulting Psychologists Press: Palo Alto, CA.

5 HARTENIAN, L.S. \& JOHNSON, N.B. (1991) "Establishing the reliability and validity of wage surveys", Public Personnel Management, 20(3): 367-83.

6 LICHTY, D. (2000) “Compensation surveys", in Berger, L.A. \& Berger, D.R. (eds.) The Compensation Handbook (4 ${ }^{\text {th }}$ ed.) McGraw-Hill: New York.

7 MIKOVICH, G.T. \& NEWMAN, J.M. (2002) Compensation (7 $7^{\text {th }}$ ed.): 229-62, McGraw-Hill: Boston.

8 RICH, J.R. \& PHALEN, C.C. (1992) “A Framework for the design of total compensation surveys”, ACA Journal, (Winter): 18-29.

9 RYNES, S.L. \& MILKOVICH, G.T. (1986) "Wage surveys: Dispelling some myths about the 'market wage'”, Personnel Psychology, (Spring): 71-90. 
10 SNELGAR, R.J. (1984) "Salary survey methods: Differences in market pay curves over a seven-year period", South African Journal of Psychology, 14(3): 75-78.

11 SNELGAR, R.J. (1986) "Salary survey methods: Comparability problems”, South African Journal of Industrial Psychology, 17(3): 16973.

12 VISWESVARAN, C. \& BARRICK, M. (1992) "Decision-making effects on compensation surveys: Implications for market wages", Journal of Applied Psychology, 77(5): 588-97.

13 WERNER, S. \& GEMEINHARDT, G. (1993) "Nonprofit organizations: What factors determine pay level?” Compensation and Benefits Review": 53-60.

14 WERNER, S., KONOPASKE, R. \& TOUCHEY, C. (1999) “Ten questions to ask yourself about compensation surveys”, Compensation and Benefits Review, 31(3): 54-59. 